\title{
Systemic changes caused by artificial insemination in beef cows (Bos indicus) and their impact on animal welfare
}

\section{Alterações sistêmicas causadas pela inseminação artificial em vacas de corte (Bos indicus) e seu impacto no bem-estar animal}

\author{
Bruna Marcele Martins de Oliveira ${ }^{1}$ (D); Rubens Paes de Arruda $^{2}$ (D); Milton Maturana Filho ${ }^{1}$ (D); \\ Eduardo Harry Birgel Júnior ${ }^{3}$ (D); Daniela Becker Birgel ${ }^{3}$ (D); Fábio Celidônio Pogliani ${ }^{4}$ (D); \\ Luisa Cunha Carneiro ${ }^{1}$ (D); Eneiva Carla Carvalho Celeghini ${ }^{*}$ (i)
}

\begin{abstract}
${ }^{1}$ Universidade de São Paulo, Centro de Biotecnologia em Reprodução Animal, Faculdade de Medicina Veterinária e Zootecnia, Departamento de Reprodução Animal, Laboratório de Ensino e Pesquisa em Patologia da Reprodução, Pirassununga - SP, Brazil

${ }^{2}$ Universidade de São Paulo, Centro de Biotecnologia em Reprodução Animal, Faculdade de Medicina Veterinária e Zootecnia, Departamento de Reprodução Animal, Laboratório de Biotecnologia do Sêmen e Andrologia, Pirassununga - SP, Brazil

${ }^{3}$ Universidade de São Paulo, Faculdade de Zootecnia e Engenharia de Alimentos, Departamento de Medicina Veterinária, Laboratório Multiusuário em Analises Clínicas Veterinárias, Pirassununga - SP, Brazil

${ }^{4}$ Universidade de São Paulo, Faculdade de Medicina Veterinária e Zootecnia, Departamento de Clínica Médica, Clinica de Bovinos e Pequenos Ruminantes, São Paulo - SP, Brazil
\end{abstract}

\begin{abstract}
This study aimed to verify if the process of artificial insemination (AI) characterized here as animal immobilization, the passage of the semen applicator through the cervix, and deposition of the semen in the uterus, affected cows' welfare. For this, 18 beef calved cows were selected and divided into two groups: inseminated cows (AIG, $n=9$ ), and not inseminated cows, the control group ( $C G, n=9)$. Body condition score, uterus, and ovary evaluation were performed. Later, both groups were submitted into an estrus synchronization protocol and only the AIG group was inseminated. Blood components of urea, creatinine, AST, GGT, CK, glucose, triglycerides, cholesterol, HDL, LDL, VLDL, NEFA, BHB, cortisol, estradiol, progesterone, albumin, and total protein were measured $30 \mathrm{~h}$ before AI, and 4, 24, 48 and $168 \mathrm{~h}$ after AI. Statistical differences were considered when $\mathrm{P}<0.05$. No differences between AIG and CG were observed. On the other hand, when the moment of insemination was evaluated, differences were observed for urea, creatinine, AST, GGT, CK, glucose, triglycerides, NEFA, BHB, albumin, and total protein. There was an oscillation of metabolic profiles depending on the time and procedures to which animals were exposed, even though it could be inferred that the AI process was incapable of altering those metabolic components on animals that were inseminated. Still, we can affirm that artificial insemination cannot be categorized as a negative reproduction tool on animal welfare. However, the containment and management procedures for AI may alter the metabolic profile of cows, especially the increase of CK.
\end{abstract}

Keywords: Human-animal relationship. Reproduction. Metabolic profile. Hormonal profile.

\section{RESUMO}

O objetivo deste estudo foi verificar se o processo de inseminação artificial (IA) caracterizado como imobilização do animal, passagem do aplicador de sêmen pelo colo do útero e deposição do sêmen no útero, afetou o bem-estar de bovinos. Para tanto, foram selecionadas 18 vacas de corte paridas, divididas em dois grupos: grupo de animais inseminados (AIG, $\mathrm{n}=9$ ) e grupo de animais não inseminados, grupo controle (GC, $n=9$ ). Foram avaliados o escore de condição corporal, útero e ovário. Posteriormente, ambos os grupos foram submetidos a um protocolo de sincronização de cio e apenas o grupo AIG foi inseminado. Componentes metabólicos como ureia, creatinina, AST, GGT, CK, glicose, triglicerídeos, colesterol, HDL, LDL, VLDL, NEFA, BHB, cortisol, estradiol, progesterona, albumina e proteína total foram mensurados 30 horas antes da IA e 4, 24, 48 e 168 horas após a IA. Diferenças estatísticas foram consideradas quando $\mathrm{P}<0,05$. Não foram observadas diferenças entre os dois grupos, por outro lado, quando o momento da inseminação foi avaliado, diferenças foram observadas para ureia, creatinina, AST, GGT, CK, glicose, triglicerídeos, NEFA, BHB, albumina e proteína total. Houve uma variação dos perfis metabólicos em função do tempo e dos procedimentos que os animais foram submetidos, embora pode-se inferir que o processo de IA não foi capaz de alterar esses componentes metabólicos 
nos animais inseminados. Ainda assim, observou-se que o processo de IA não foi categorizado como uma ferramenta negativa de reprodução com relação ao bem-estar animal. Porém, ainda assim, os procedimentos de contenção e manejo da IA podem alterar o perfil metabólico das vacas, principalmente o aumento da CK.

Palavras-chave: Interação homem-animal. Reprodução. Perfil metabólico. Perfil hormonal.

\section{Correspondence to:}

Eneiva Carla Carvalho Celeghini

Universidade de São Paulo, Faculdade de Medicina Veterinária e Zootecnia, Departamento de Reprodução Animal, Centro de Biotecnologia em Reprodução Animal, Laboratório de Ensino e Pesquisa em Patologia da Reprodução

Av. Duque de Caxias Norte, 225

CEP: 13635-900, Pirassununga - SP, Brazil

e-mail: celeghin@usp.br

Received: April 02, 2021

Approved: June 22, 2021

How to cite: Oliveira BMM, Arruda RP, Maturana Filho M, Birgel Júnior EH, Birgel DB, Pogliani FC, Carneiro LC, Celeghini ECC. Systemic changes caused by artificial insemination in beef cows (Bos indicus) and their impact on animal welfare. Braz J Vet Res Anim Sci. 2021;58:e183731. https://doi. org/10.11606/issn.1678-4456.bjvras.2021.183731

\section{Introduction}

Animal welfare is a growing global concern, and its importance to animals and role in the final product is unquestionable. The demand for so-called safe products with quality certification has increased in the market so that these parameters are required by national and international customers (Assis et al., 2011).

To achieve products with high quality, breeding strategies are developed for the beef industry either by conventional methods or novel technologies. These advanced tools have a strong influence on animal health and welfare. Some technologies, though, are not yet fully explored. This makes it necessary to confirm if modern tools cause positive or negative effects in the production, in addition to the respective impacts of genetic and environmental factors (Clark et al., 2006).

According to Rutledge (2001), many situations can affect animal welfare, especially those that can cause stress and consequently affect the reproductive process. These include, for example, excessive immobilization before artificial insemination (AI), the use of aggressive tools, separation of the animals, and others. The AI technique requires human contact most of the time. Also, the understanding of how cows with different behaviors perceive this interaction is essential for improving the quality of the relationship between humans and animals, and therefore improving animal welfare in commercial farms (Shahin, 2018).

Some indicators can be used to assess animal welfare during breeding programs. One way to evaluate the general condition of the herd is to measure the body condition score (BCS), which is reflected in blood concentrations of non-esterified fatty acids (NEFA), and beta-hydroxybutyrate (BHB) as both are related in lipid mobilization reserves. Still, the measurement of plasma cortisol has also been used to analyze the stressful effects of animal management on animal welfare (Broom \& Fraser, 2007).

This study is the first in evaluating punctually the systemic changes caused by the AI technique in beef cows, as it was only explored before in dairy cows. Based on that, this study aimed to verify if the process of AI (characterized here as animal immobilization, the passage of the semen applicator through the cervix, and deposition of the semen in the uterus) caused changes in renal, hepatic, energetic, hormonal and protein profiles in different periods related to animal welfare, which could reflect systemically in the performance of these animals.

\section{Material and Methods}

\section{Animals and experiment design}

All the procedures of this study were in agreement with Ethical Principles in Animal Research adopted by the "Ethics Committee in the Use of Animals" of the School of Veterinary Medicine and Animal Science of the University of São Paulo, São Paulo, Brazil under the protocol number 2528/2012.

The experiment was conducted at the Laboratory of Biotechnology of Semen and Andrology of the Center for Biotechnology in Animal Reproduction of the Department of Animal Reproduction of the School of Veterinary Medicine and Animal Science (University of São Paulo, Pirassununga, São Paulo, Brazil); in the Laboratory of Multi-User Veterinary Clinical Analysis from the Department of Veterinary Medicine, School of Animal Science and Food Engineering (University of São Paulo, Pirassununga, São Paulo, Brazil), and at the Genesis Institute for Scientific Analysis (São Paulo, São Paulo, Brazil).

A total of 18 beef calved cows (Bos indicus), between 50 and 90 days postpartum, were randomly divided into two groups. One group was submitted to a synchronization 
protocol and artificial insemination technique (AIG, $n=9$ ), and the other was submitted to a synchronization protocol and not artificially inseminated, which was the control group (CG, $\mathrm{n}=9$ ).

The cows were kept in a pasture with ad libitum access to water and mineral supplement. They were free from any anatomical and reproductive disorders and not suffering from any health problems. The animal health calendar was followed regularly for the entire herd according to the state law for beef cattle.

\section{Reproduction management design}

The cows were previously evaluated for the health and integrity of the reproductive tract. The BCS was evaluated on a scale of 1- very thin to 5- obese, adjusted to 0.25 (Ferguson et al., 1994). Only animals with a BCS above 2.50 were selected to be part of the experiment.

Transrectal ultrasonography (M5vet, Mindray", China) was performed to evaluate the genital tract as uterus and ovary. The uterus was evaluated and classified on a scale from 1 to 3 , as (1) uterus with complete involution, without liquid; (2) uterus with a small amount of liquid, with incomplete involution and little distension, and (3) uterus with liquid, being able to present some type of infection, distended and without involution (Oliveira et al., 2014).

The ovaries were evaluated and classified on a scale from 1 to 3 , as (1) ovaries with diameter more than $30 \mathrm{~mm}$, containing growing follicles with a diameter more than $8.5 \mathrm{~mm}$ in the presence of a corpus luteum or follicles larger than $12 \mathrm{~mm}$ in the absence of corpus luteum; (2) ovaries less than $30 \mathrm{~mm}$ of size with follicles between 5 and $8.5 \mathrm{~mm}$, and (3) ovaries with a diameter smaller than $12 \mathrm{~mm}$ with follicles more than $5 \mathrm{~mm}$ in diameter (Madureira \& Pimentel, 2005) Those animals that had uterine and/or ovaries classified as parameter 3 were excluded from the experiment.

After uterus and ovaries were evaluated, both groups were submitted to an estrus synchronization protocol as follows: Day 0- insertion of a subcutaneous implant (3 mg norgestomet, Crestar, MSD Animal Health, Boxmeer, Holland, The Netherlands) + intramuscular (IM) application of $2 \mathrm{mg}$ estradiol benzoate (Estrogin', Biofarm, Jaboticabal, Brazil), day 9- withdrawal of Crestar (MSD Animal Health, Boxmeer, Holland, The Netherlands) $+1 \mathrm{mg}$ of estradiol benzoate IM (Sincrodiol', Ouro Fino, Cravinhos, Brazil) $+0.5 \mathrm{mg}$ of cloprostenol sodium IM (Sincrocio ${ }^{\circ}$ Ouro Fino, Cravinhos, Brazil) +300 IU of equine chorionic gonadotrophin IM (Novormon', MSD Animal Health, Boxmeer, Holland, The Netherlands).

The AI process (animal immobilization, passage of the semen applicator through the cervix, and deposition of the semen in the uterus), was performed $30 \mathrm{~h}$ later only in the AIG group ( $\mathrm{n}=9)$ (Figure 1).

For the AIG group, doses of semen from a Nellore (Bos indicus) bull were subject to a prior assessment. The inseminations were all performed by the same experienced inseminator. For the AI procedure, the semen was thawed at $37^{\circ} \mathrm{C}$ for $30 \mathrm{sec}$.

\section{Animals' systemic evaluation}

Blood samples were collected in both groups by external jugular vein puncture using the Vacutainer (BD, New Jersey, United States) system, $30 \mathrm{~h}$ before $\mathrm{AI}$ and at 4, 24, 48, and $168 \mathrm{~h}$ after AI. Blood was centrifuged (Center bio Clinical Centrifuge, model $80-2 \mathrm{~B}-15 \mathrm{~mL}, 420 \mathrm{~g}$ ) for $15 \mathrm{~min}$, and

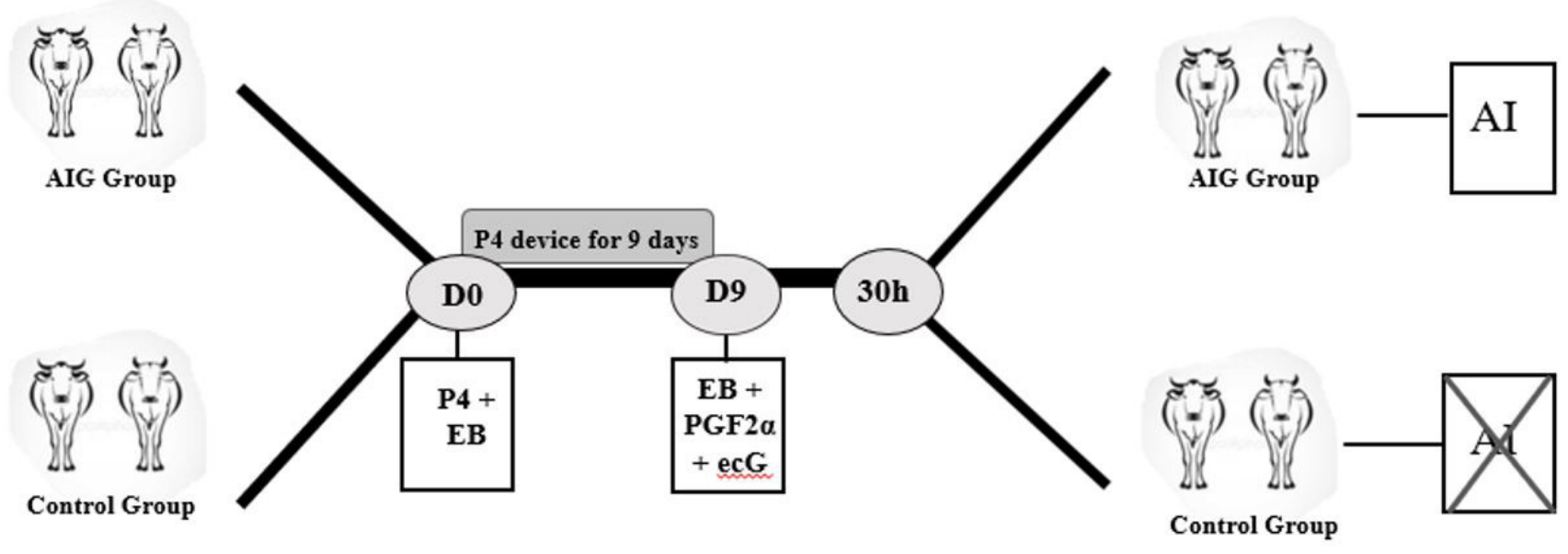

Figure 1 - Schematic figure to describe the synchronization protocol used in both groups. After $30 \mathrm{~h}$ the AIG group was inseminated, whereas the control group was not inseminated. AIG: artificial insemination group; D0: day 0; D9: day 9; P4: progesterone; EB: estradiol benzoate; PGF2 $\alpha$ : prostaglandin F2 $\alpha$; eCG: equine chorionic gonadotropin; AI: artificial insemination. 
serum and plasma were separated with triplicate pipettes into $1.5 \mathrm{~mL}$ microtubes, identified and frozen at $-80^{\circ} \mathrm{C}$.

Urea and creatinine were measured to evaluate renal profiles. For liver profile, aspartate aminotransferase (AST), gamma-glutamyl transferase (GGT), and creatine kinase (CK) were measured. The energy profile was evaluated by glucose, triglycerides, cholesterol, high-density lipoproteins (HDL), low-density lipoproteins (LDL), very-low-density lipoprotein (VLDL), non-esterified fatty acids (NEFA), and beta-hydroxybutyrate (BHB). For hormonal evaluations, cortisol, estradiol, and progesterone were measured. The protein profile was evaluated by a proteinogram, considering albumin and total protein values.

All the metabolites were quantified using an automatic biochemical analyzer (RX Daytona), using specific kits (Randox:, Northern Ireland), for urea (UR3825), creatinine (CR3814), AST (AS3804), GGT (GT3817), CK (CK110), glucose (GL3815), triglycerides (TR3823), total cholesterol (CH3814), BHB, (BHBA; RB1007), NEFA (FA115), HDL (CH3811). The values of LDL and VLDL were calculated by mathematical formulas $(\mathrm{VLDL}=$ triglycerides $/ 5$ and $\mathrm{LDL}=$ total cholesterol - HDL - VLDL mg/dL) (Friedewald et al., 1972). Analyses were performed at $37^{\circ} \mathrm{C}$.

The evaluations of hormones (cortisol, estradiol, progesterone) were performed by the radioimmunoassay technique, using specific kits (cortisol: IM1841; estradiol: Ultra-Sensitive Estradiol RIA, DSL4800, progesterone: IM1188, Immunotech').

\section{Immobilization management}

During all the experiments, the animals were immobilized seven times. The first time animals were immobilized for selection. The second, fourth, fifth, sixth, and seventh time animals were immobilized for blood samples. At the third immobilization, AI was performed. (Figure 2).

\section{Statistical analysis}

The variables were evaluated for the normality of the residues by the Shapiro-Wilk test and homogeneity of the variances by the Levene test. After the outliers were removed, data were analyzed through combined procedure (PROC MIXED) of the Statistical Analysis Software [version 9.2, 2010, SAS Institute, North Carolina State University, USA], using a model for time-repeated measures, evaluating group effect, time effect, and interaction between group and time.

The matrices were tested and the one with the lowest AIC was used. The Tukey test was used to compare the means and statistical differences were considered when $\mathrm{P}<0.05$. Since there was no interaction between group and time,
Numbers of immobilization

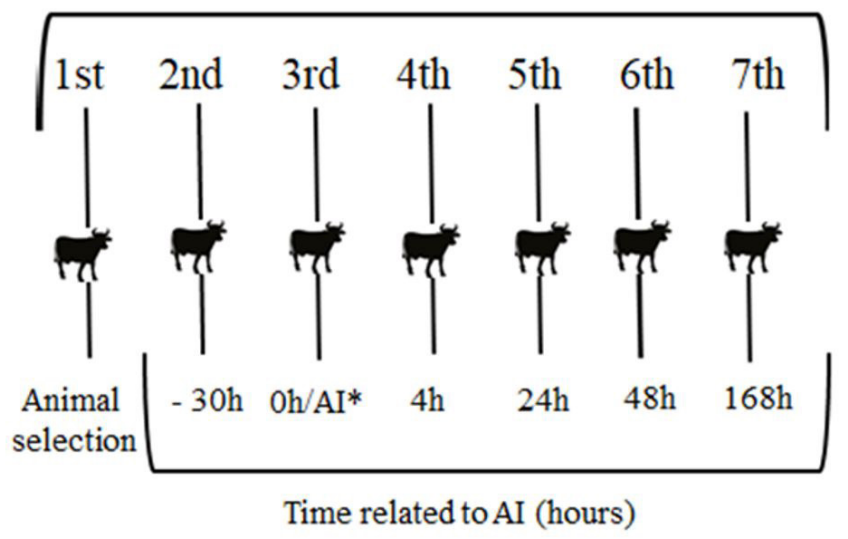

Figure 2-Numbers of immobilization and its respective moment according to the artificial insemination (AI) procedure on beef suckled cows. *AI procedure was performed during the $3^{\text {rd }}$ immobilization.

data were presented according to the group, regardless of the time, and according to the time, regardless of the group.

\section{Results}

\section{Metabolic components}

The AIG and Control groups did not differ in renal, hepatic, energetic, hormonal, and proteinogram profiles (Table 1).

Based on that, the mean of the groups was performed to evaluate each variable before and after the AI procedure. When these variables were measured according to the moment of insemination differences were observed (Table 2). For renal profile, urea was reduced 4 and $168 \mathrm{~h}$ after AI compared to $30 \mathrm{~h}$ before and $24 \mathrm{~h}$ after AI $(\mathrm{P}<0.05)$. Still, $48 \mathrm{~h}$ after AI, lower values of urea were detected than $24 \mathrm{~h}$ after AI $(\mathrm{P}<0.05)$. For creatinine, a lower value was found $24 \mathrm{~h}$ after AI when compared to $30 \mathrm{~h}$ before AI $(\mathrm{P}<0.05)$ and did not differ between other periods ( $\mathrm{P}>0.05$; Table 2 ).

In the hepatic profile there was an increase in AST 24 and $48 \mathrm{~h}$ after AI compared to $30 \mathrm{~h}$ before AI $(\mathrm{P}<0.05)$ and did not differ between other moments $(\mathrm{P}>0.05)$. On the other hand, GGT increased only $4 \mathrm{~h}$ after AI compared to $30 \mathrm{~h}$ before $\mathrm{AI}$, remaining similar in others periods. For $\mathrm{CK}$, there was an increase in its values 4 and $24 \mathrm{~h}$ after AI compared to $30 \mathrm{~h}$ before and $168 \mathrm{~h}$ after $\mathrm{AI}(\mathrm{P}<0.05)$, but similar to values found $48 \mathrm{~h}$ after AI ( $\mathrm{P}>0.05$; Table 2$)$.

When the energetic profile was evaluated, the highest concentration of glucose was observed $4 \mathrm{~h}$ after AI compared to $30 \mathrm{~h}$ before AI. For triglycerides, higher values were observed $30 \mathrm{~h}$ before AI with those observed 24, 48, and $168 \mathrm{~h}$ after AI, not differing from that $4 \mathrm{~h}$ after AI. No 
Table 1 - Means \pm SD for blood components that characterize renal (urea and creatinine), hepatic (AST, GGT, and CK), energetic (glucose, triglycerides, cholesterol, HDL, LDL, VLDL, NEFA, and BHB), hormonal (cortisol, estradiol, and progesterone), and protein profiles (albumin and total protein) from control groups (CG) and artificially inseminated groups (AIG) in beef cows

\begin{tabular}{|c|c|c|c|c|}
\hline Profile & Variable & Control group & Al group & PValue \\
\hline \multirow[t]{2}{*}{ Renal } & Urea (mg/dL) & $15.94 \pm 1.03$ & $16.00 \pm 1.12$ & 0.965 \\
\hline & Creatinine $(\mathrm{mg} / \mathrm{dL})$ & $1.47 \pm 0.04$ & $1.46 \pm 0.03$ & 0.865 \\
\hline \multirow[t]{3}{*}{ Hepatic } & AST (U/L) & $143.92 \pm 12.11$ & $150.62 \pm 10.93$ & 0.683 \\
\hline & GGT (U/L) & $5.76 \pm 1.11$ & $6.29 \pm 1.24$ & 0.754 \\
\hline & CK (U/L) & $1432.09 \pm 287.02$ & $1260.63 \pm 164.89$ & 0.606 \\
\hline \multirow[t]{8}{*}{ Energetic } & Glucose (mg/dL) & $8.97 \pm 4.61$ & $95.00 \pm 5.19$ & 0.333 \\
\hline & Triglycerides (mg/dL) & $27.60 \pm 2.47$ & $27.24 \pm 2.63$ & 0.923 \\
\hline & Cholesterol (mg/dL) & $166.21 \pm .30$ & $165.24 \pm 7.65$ & 0.936 \\
\hline & HDL (mg/dL) & $75.24 \pm 1.48$ & $79.47 \pm 3.30$ & 0.293 \\
\hline & LDL (mg/dL) & $85.44 \pm 8.93$ & $80.31 \pm 4.72$ & 0.596 \\
\hline & VLDL (mg/dL) & $4.81 \pm 0.45$ & $5.27 \pm 0.35$ & 0.430 \\
\hline & NEFA (mmol/L) & $0.96 \pm 0.09$ & $0.92 \pm 0.08$ & 0.790 \\
\hline & $\mathrm{BHB}(\mathrm{mg} / \mathrm{dL})$ & $7.08 \pm 0.61$ & $8.20 \pm 0.49$ & 0.160 \\
\hline \multirow[t]{3}{*}{ Hormonal } & Cortisol (nM/L) & $51.99 \pm 5.76$ & $74.87 \pm 17.20$ & 0.220 \\
\hline & Estradiol (pg/mL) & $2.24 \pm 0.52$ & $2.49 \pm 0.50$ & 0.734 \\
\hline & Progesterone (ng/mL) & $0.70 \pm 0.06$ & $0.91 \pm 0.17$ & 0.273 \\
\hline \multirow[t]{2}{*}{ Protein } & Albumin (g/dL) & $3.22 \pm 0.05$ & $3.15 \pm 0.04$ & 0.267 \\
\hline & Total Protein (mg/dL) & $8.22 \pm 0.07$ & $8.07 \pm 0.08$ & 0.098 \\
\hline
\end{tabular}

AST: aspartate aminotransferase, GGT: gamma-glutamyl transferase, CK: creatinine kinase, HDL: high-density lipoproteins, LDL: low-density lipoproteins, VLDL: very-low-density lipoproteins, NEFA: non-esterified fatty acids, BHB: beta-hydroxybutyrate.

Table 2 - Means \pm SD for blood components that characterize renal (urea and creatinine), hepatic (AST, GGT, and CK), energetic (glucose, triglycerides, cholesterol, HDL, LDL, VLDL, NEFA, and BHB), hormonal profiles (cortisol, estradiol, and progesterone) and protein (albumin and total protein) according to each evaluation time: $30 \mathrm{~h}$ before AI, and 4, 24, 48, $168 \mathrm{~h}$ after $\mathrm{AI}$ in beef cows

\begin{tabular}{|c|c|c|c|c|c|c|c|}
\hline \multirow{2}{*}{ Profile } & \multirow{2}{*}{ Variable } & \multicolumn{5}{|c|}{ Time related to Al (hours) } & \multirow{2}{*}{$P$ value } \\
\hline & & -30 & 4 & 24 & 48 & 168 & \\
\hline \multirow[t]{2}{*}{ Renal } & Ureia (mg/dL) & $19.47 \pm 1.71^{\mathrm{ab}}$ & $11.39 \pm 0.75^{c}$ & $21.11 \pm 0.96^{a}$ & $15.41 \pm 1.02^{b c}$ & $11.82 \pm 0.57^{c}$ & $<0.0001$ \\
\hline & $\begin{array}{l}\text { Creatinine (mg/ } \\
\mathrm{dL})\end{array}$ & $1.58 \pm 0.06^{\mathrm{a}}$ & $1.55 \pm 0.05^{\mathrm{ab}}$ & $1.37 \pm 0.03^{b}$ & $1.46 \pm 0.04^{\mathrm{ab}}$ & $1.42 \pm 0.04^{\mathrm{ab}}$ & 0.02 \\
\hline \multirow[t]{3}{*}{ Hepatic } & AST (U/L) & $98.22 \pm 3.83^{b}$ & $139.27 \pm 12.37^{a b}$ & $155.66 \pm 17.17^{a}$ & $146.88 \pm 12.54^{a}$ & $110.50 \pm 6.40^{\mathrm{ab}}$ & 0.0001 \\
\hline & GGT (U/L) & $2.88 \pm 0.72^{\mathrm{b}}$ & $7.16 \pm 1.46^{\mathrm{a}}$ & $4.11 \pm 1.01^{\mathrm{ab}}$ & $6.72 \pm 01.69^{\mathrm{ab}}$ & $6.55 \pm 1.60^{\mathrm{ab}}$ & 0.048 \\
\hline & CK (U/L) & $199.52 \pm 36.18^{b}$ & $1544.81 \pm 321.62^{\mathrm{a}}$ & $1566.88 \pm 324.01^{\mathrm{a}}$ & $927.37 \pm 169.51^{\mathrm{ab}}$ & $167.62 \pm 28.77^{b}$ & $<0.0001$ \\
\hline \multirow[t]{8}{*}{ Energetic } & $\begin{array}{c}\text { Glucose (mg/ } \\
\mathrm{dL})\end{array}$ & $84.41 \pm 4.60^{b}$ & $113.36 \pm 9.47^{a}$ & $90.32 \pm 4.59^{\mathrm{ab}}$ & $91.11 \pm 5.18^{\mathrm{ab}}$ & $106.49 \pm 8.02^{\mathrm{ab}}$ & 0.040 \\
\hline & $\begin{array}{l}\text { Triglycerides } \\
\text { (mg/dL) }\end{array}$ & $41.56 \pm 2.07^{\mathrm{a}}$ & $30.77 \pm 1.70^{\mathrm{ab}}$ & $23.64 \pm 3.11^{\mathrm{b}}$ & $21.23 \pm 1.95^{\mathrm{b}}$ & $24.893 \pm 1.672^{\mathrm{b}}$ & $<0.0001$ \\
\hline & $\begin{array}{l}\text { Cholesterol } \\
\text { (mg/dL) }\end{array}$ & $180.27 \pm 8.78$ & $174.47 \pm 10.30$ & $180.44 \pm 10.59$ & $172.15 \pm 9.70$ & $159.24 \pm 10.18$ & 0.484 \\
\hline & $\mathrm{HDL}(\mathrm{mg} / \mathrm{dL})$ & $80.57 \pm 2.89$ & $82.21 \pm 3.51$ & $82.25 \pm 3.62$ & $78.32 \pm 3.23$ & $74.18 \pm 3.52$ & 0.327 \\
\hline & $\mathrm{LDL}(\mathrm{mg} / \mathrm{dL})$ & $91.46 \pm 6.63$ & $86.10 \pm 7.34$ & $93.45 \pm 7.77$ & $89.58 \pm 7.04$ & $77.91 \pm 7.71$ & 0.560 \\
\hline & VLDL (mg/dL) & $8.31 \pm 0.41^{\mathrm{a}}$ & $6.15 \pm 0.34^{\mathrm{ab}}$ & $4.73 \pm 0.62^{b}$ & $4.24 \pm 0.39^{b}$ & $7.14 \pm 2.19^{\mathrm{ab}}$ & $<0.0001$ \\
\hline & NEFA (mmol/L) & $0.78 \pm 0.0 .08^{\mathrm{ab}}$ & $0.78 \pm 0.10^{\mathrm{ab}}$ & $1.13 \pm 0.10^{\mathrm{a}}$ & $0.91 \pm 0.10^{\mathrm{ab}}$ & $0.68 \pm 0.09^{b}$ & 0.031 \\
\hline & $\mathrm{BHB}(\mathrm{mg} / \mathrm{dL})$ & $5.14 \pm 0.34^{c}$ & $5.93 \pm 0.37^{\mathrm{bc}}$ & $7.25 \pm 0.66^{b}$ & $9.74 \pm 0.66^{a}$ & $5.27 \pm 0.37^{\mathrm{bc}}$ & $<0.001$ \\
\hline \multirow[t]{3}{*}{ Hormonal } & Cortisol (nM/L) & $60.82 \pm 7.03$ & $88.06 \pm 12.10$ & $75.79 \pm 14.96$ & $66.91 \pm 11.76$ & $75.49 \pm 9.25$ & 0.416 \\
\hline & $\begin{array}{l}\text { Estradiol (pg/ } \\
\mathrm{mL})\end{array}$ & $1.21 \pm 0.22^{\mathrm{bc}}$ & $5.38 \pm 1.00^{\mathrm{a}}$ & $3.38 \pm 0.67^{\mathrm{ab}}$ & $1.48 \pm 0.28^{\mathrm{bc}}$ & $0.73 \pm 0.17^{c}$ & 0.0001 \\
\hline & $\begin{array}{l}\text { Progesterone } \\
(\mathrm{ng} / \mathrm{mL})\end{array}$ & $3.25 \pm 1.17^{\mathrm{ab}}$ & $0.93 \pm 0.17^{b}$ & $1.22 \pm 0.28^{b}$ & $0.98 \pm 0.23^{b}$ & $5.85 \pm 0.97^{a}$ & 0.0007 \\
\hline \multirow[t]{2}{*}{ Protein } & Albumin (g/dL) & $3.41 \pm 0.04^{\mathrm{a}}$ & $3.35 \pm 0.04^{\mathrm{a}}$ & $3.11 \pm 0.06^{b}$ & $3.10 \pm 0.05^{b}$ & $3.07 \pm 0.04^{b}$ & $<0.0001$ \\
\hline & $\begin{array}{l}\text { Total Protein } \\
\text { (mg/dL) }\end{array}$ & $7.48 \pm 0.15^{b}$ & $8.29 \pm 0.06^{a}$ & $8.40 \pm 0.07^{a}$ & $8.35 \pm 0.09^{\mathrm{a}}$ & $8.21 \pm 0.07^{a}$ & 0.0003 \\
\hline
\end{tabular}


differences were observed in cholesterol, HDL, and LDL concentrations between the moments evaluated $(\mathrm{P}>0.05)$. Groups showed similar concentrations of NEFA in all moments that were immobilized. When BHB was measured, a higher concentration $48 \mathrm{~h}$ after AI was noticed when compared to other moments $((\mathrm{P}<0.05$; Table 2$)$.

\section{Hormonal components}

When cortisol was measured, no changes were observed ( $\mathrm{P}>0.05 ;$ Table 2). On the other hand, the highest estradiol value was noticed $4 \mathrm{~h}$ after AI, followed by similar values that were observed $24 \mathrm{~h}$ after AI. The latter was similar to those found $48 \mathrm{~h}$ after $\mathrm{AI}$ and $30 \mathrm{~h}$ before $\mathrm{AI}$, and the lowest estradiol values appeared $168 \mathrm{~h}$ after AI, which was not statistically different from values found $48 \mathrm{~h}$ after AI and $30 \mathrm{~h}$ before AI $(\mathrm{P}<0.05)$. An intermediate value for progesterone concentration was observed $30 \mathrm{~h}$ before AI and the values were maintained at basal levels between 4 and $48 \mathrm{~h}$ after ovulation, peaking $168 \mathrm{~h}$ after AI (Table 2).

\section{Proteinogram profile}

The highest values of albumin were observed $30 \mathrm{~h}$ before $\mathrm{AI}$ and $4 \mathrm{~h}$ after AI, reducing 24, 48, and $168 \mathrm{~h}$ after AI. After $24 \mathrm{~h}$ we found albumin values were maintained at lower levels than those found in previous periods. For total proteins, the lowest value was observed $30 \mathrm{~h}$ before $\mathrm{AI}$ and $24 \mathrm{~h}$ after $\mathrm{AI}$ it was increased and remained high up to $168 \mathrm{~h}$ after AI (Table 2).

\section{Discussion}

All the procedures performed for TAI, such as animal immobilization, insertion of progesterone device, and application of intramuscular injections, are stressful for the animals, even if they are performed under caution. Beef cattle are more susceptible to handling stress due to the extensive breeding system that is maintained. The TAI process involves human contact most of the time. Yet only one study on a commercial beef farm investigated farmers' attitudes towards handling, but it did not investigate the relationship between these attitudes and animal behavior (Destrez et al., 2018).

In this study, we investigated possible changes in renal, hepatic, energetic, hormonal, and protein profiles in different periods related to animal welfare, which could reflect systemically in the performance of these animals.

\section{The metabolic profile between groups}

It was not expected that renal profile presented differences between groups since the animals were maintained under the same conditions and same procedures. The amount of creatinine formed per day is dependent on muscle mass (Kaneko et al., 2008), which explained the difference of this metabolite between groups since this research had homogenous animals with similar BCS. The changes that occurred over time for urea and creatinine are shown in Table 2. For both variables, a time effect was observed. However, the small change that has been noted according to the evaluation periods could be explained by the fact that even though it is relatively constant for an individual, it can be slightly altered due to feeding, mainly by protein intake (Kaneko et al., 2008).

According to Barros Filho (1995), the creatinine profile for Nellore cows of reproductive age in Brazil ranges from 1.76 to $1.85 \mathrm{mg} / \mathrm{dL}$. In both groups and during evaluation, creatinine values were lower than those suggested by the author. However, the animals did not present any physical indication that could suggest that these values could reflect in any renal alteration.

When the hepatic profile was evaluated, no difference between the groups for AST and CK profiles was expected, since these were dosed together to specify whether the increase in AST is due to liver or muscle injury. Also, it was important to measure $\mathrm{CK}$ as it is a highly specific muscle indicator that is sensitive and stable (Shpigel et al., 2003). In this study, the muscle activity of the groups was similar, since all animals were managed in the same way. According to Peixoto et al. (2006), AST can be evaluated as a marker of liver function, but its alterations may also be related to muscle metabolism. The results of this experiment demonstrated that the increase in AST was due to muscle activity and not alteration of liver function since there was an alteration of CK simultaneously.

It is possible to infer that the difference in concentrations of AST and CK that occurred during the periods evaluated (Table 2) were due to an intense muscular activity caused by intramuscular hormone applications, forced exercises, and muscular stress caused by the numerous immobilizations (Figure 1). The highest values were found between 4 and $48 \mathrm{~h}$ after AI for both AST and CK profiles, which was the period of an intense activity realized by the animals. For these two enzymes, the values observed when the animals were not yet in intense activity ( $30 \mathrm{~h}$ before AI) or when they had a rest period between the evaluations ( $168 \mathrm{~h}$ after AI) were lower when compared to intense activity (Table 2). This assumption may be reinforced by Shpigel et al. (2003), who noticed an increase in CK enzyme when muscle activity was prolonged. 
According to Herdt (2000), the synthesis of glucose is dependent on the perfect functioning of the liver, as it is an organ that regulates the concentration of this metabolite in the blood and its supply to the tissues. Considering that the liver profile between the groups was not different (Table 1), it was understood that the activity of this organ was similar for all animals. Therefore, it would not be expected that the glucose presented a different concentration between groups (Table 1).

Another fact that supports the hypothesis that the difference in glucose concentration was not expected between the groups was that this alteration is only expected in animals of different ages, since according to Wathes et al. (2007), low blood glucose concentrations may be caused by glucose demand that reproductive activities require. In this experiment, all animals were reproductively active and therefore no differences in the concentrations of this metabolite were expected. But changes in glucose concentration were significant according to the different moments evaluated (Table 2). These results challenge those from Kenny et al. (2002), who observed that there was no variation of glucose concentrations between estrous cycle phases.

Triglycerides comprise fat and are related to functions such as stock and energy reserve and thermal insulation, and can be stored in large amounts in adipose tissue (Kaneko et al., 2008). In this study, since the animals were homogeneously distributed based on the BCS no difference between the groups was observed (Table 1). On the other hand, we observed a decrease in triglyceride values over time (Table 2). This alteration was possibly due to the physical exercise required for the animals and by the stress caused by the procedures.

No differences between groups were observed for cholesterol (Table 1) since the hepatic profile of the groups was similar. The groups also had similar concentrations of HDL and LDL (Table 1). This theory was reinforced by the fact that the groups had similar concentrations of VLDL (Table 1) since this lipoprotein is also responsible for driving cholesterol. According to Hocquette \& Bauchart (1999), VLDL mainly performs the transport of triglycerides, which in this experiment was similar between groups. Moreover, no differences were observed in cholesterol, $\mathrm{HDL}$, and LDL concentrations between those periods evaluated (Table 2).

When the NEFA profile was evaluated, no difference between groups was related (Table1). According to Kaneko et al. (2008), NEFAs are produced in large quantities by the liver, adipose tissue, and mammary gland. As previously reported, the hepatic profile of the animals was similar between groups. In addition, Mondal \& Prakash (2004) affirmed that the concentration of NEFA reflects the degree of lipolysis of the animal, that is, how much is being demanded by the organism to meet the energy needs. This statement also agrees with the results found in this experiment, since the animals were under the same dietary conditions and had similar energy needs as all the animals were lactating and underwent the same exercise requirements.

During the different times evaluated, NEFA had its higher concentration $24 \mathrm{~h}$ after AI when compared to $168 \mathrm{~h}$ after AI, and the results were similar in the other evaluation periods (Table 2). We observed that during the period of intense activity of the animals $(4,24$, and $48 \mathrm{~h}$ after AI) NEFA values were higher when compared to $168 \mathrm{~h}$ after AI, possibly because the animals had about five days of rest and feeding.

According to Peixoto et al. (2006), as well as NEFA, $\mathrm{BHB}$ is related to the metabolic rate of lipid reserves, so no difference in concentration of this metabolite between CG and AIG was quantified (Table 1). However, the lowest values of $\mathrm{BHB}$ were $30 \mathrm{~h}$ before $\mathrm{AI}$, and it gradually increased during the experiment, possibly due to the energy demand that the activities required of the animals, reaching a peak $48 \mathrm{~h}$ after AI, and decreased when the animals rest between evaluations (Table 2).

\section{Hormonal profiles between groups}

According to Greco \& Stabenfeldt (2008), cortisol is one of the main hormones related to the stress response. Based on that, it was expected that AIG presented a higher cortisol concentration than the CG since during the AI process the animals had to undergo stressful management. However, the stress level measured by cortisol concentration was similar between groups (Table 1). Doornenbal et al. (1988) related that the mean value of cortisol for beef cattle was $68.9 \mathrm{nM} / \mathrm{L}$. Our study showed that CG was below this parameter, while the AIG was above. In a study conducted by Doornenbal et al. (1988) they observed that at 4, 24, and $168 \mathrm{~h}$ after AI, the animals had cortisol concentrations above normal levels established by the literature, which was not observed in this experiment.

For estradiol, no differences were reported between groups (Table 1). The highest estradiol value was $4 \mathrm{~h}$ after AI, followed by similar values that were observed $24 \mathrm{~h}$ after AI. The latter was similar to those found $48 \mathrm{~h}$ after AI and 30 hours before AI and the lowest estradiol values appeared $168 \mathrm{~h}$ after AI, which was not statistically different from values found $48 \mathrm{~h}$ after AI and $30 \mathrm{~h}$ before AI (Table 2). When a peak of estradiol was observed ( $4 \mathrm{~h}$ after AI), it was probably by the application of $1 \mathrm{mg}$ of estradiol benzoate, which was 
performed when progesterone implant was withdrawn, and by the production of estradiol in the follicular phase of the animals, which was also stimulated by the application of $300 \mathrm{IU}$ of equine chorionic gonadotropin. After that, it was possible to observe a gradual decrease of this hormone, since ovulation occurred and consequently the progesterone caused negative feedback in the hypothalamic axis.

The concentration of progesterone was similar between groups (Table 1), although we observed that the concentration of progesterone gradually increased over time. The dosages performed $168 \mathrm{~h}$ after AI were close to those expected for the peak of this hormone that happens 10 days after ovulation and, according to (Viana et al., 1999), it reaches a value close to $7.5 \mathrm{ng} / \mathrm{mL}$.

\section{Proteinogram values between groups}

After semen deposition in the reproductive tract, the females develop an acute inflammatory reaction. This response is short-lived and, in addition to a local reaction, there is also a systemic reaction, called an acute phase response (Bilate, 2007). Based on that, we expected that AIG had lower albumin values than CG. However, no difference between groups in this study was observed (Table 1).

The proteinogram suggested that the inflammatory reaction that occurred after AI was not able to systemically reflect the production of acute-phase proteins in the blood. We noted that after 24 hours, albumin values were maintained at lower levels than those found in previous periods. Cerón et al. (2005) and Calazans et al. (2009) cited that some acute-phase proteins had their concentration decreased during the acute phase response and among them, albumin could be cited. These results encompass the albumin values of AIG and CG and suggest that the procedures performed in both groups, and not only semen deposition in the reproductive tract, caused an inflammatory response that resulted in the decrease of albumin values.

\section{References}

Assis DR, Rezende-Lago NCM, Marchi PGF, Amato CCA. Direct losses due abscesses and bruised in beef carcasses. Rev Port Ciênc Vet. 2011;106(577-580):47-51.

Barros Filho IR. Contribuição ao estudo da bioquímica clínica em zebuínos da raça Nelore (Bos indicus, Linnaeus 1758) criados no estado de São Paulo [dissertation]. São Paulo: Faculdade de Medicina Veterinária e Zootecnia, Universidade de São Paulo; 1995.
For total proteins, the lowest value was observed $30 \mathrm{~h}$ before AI. After $24 \mathrm{~h}$ following AI, this value increased and remained high up to $168 \mathrm{~h}$ after AI (Table 2). The total protein values found in this experiment were following those established by Kaneko et al. (2008).

In this experiment, the changes observed in each time evaluated demonstrated that although some metabolites had supposedly been altered for the same cause, the intensity and time that this change took place may be different for each variable.

\section{Conclusion}

The artificial insemination process is not capable of altering changes in renal, hepatic, energetic, hormonal, and protein profiles when compared between groups inseminated versus not inseminated. Still, we can affirm that artificial insemination cannot be categorized as a negative reproduction tool on animal welfare.

\section{Conflict of Interest}

The authors declare no conflicts of interest.

\section{Ethics Statement}

All the procedures of this study were in agreement with Ethical Principles in Animal Research adopted by the "Ethics Committee in the Use of Animals" of the School of Veterinary Medicine and Animal Science of the University of São Paulo, São Paulo, Brazil under the protocol number 2528/2012.

\section{Acknowledgements}

The authors thank the São Paulo State Research Foundation (FAPESP) for their financial support (process numbers 2011/22833-9 and 2014/12757-1).

Bilate AMB. Inflamação, citocinas, proteínas de fase aguda e implicações terapêuticas. Temas Reumatol Clínica. 2007;8(2):47-51.

Broom DM, Fraser AF. Domestic animal behaviour and welfare. Wallingford: CAB International; 2007.

Calazans SG, Daleck CR, Fagliari JJ, Repetti CF, Nardi AB, Castro JHT, Fernandes SC, César JRF, Rodigheri SM. 
Serum protein concentrations in healthy dogs and dogs with lymphoma by means of sodium dodecil sulphatepolyacrylamide gel electrophoresis (SDS-PAGE). Arq Bras Med Vet Zootec. 2009;61(5):1044-8. http://dx.doi. org/10.1590/S0102-09352009000500005.

Cerón JJ, Eckersall PD, Martínez-Subiela S. Acute phase proteins in dogs and cats: current knowledge and future perspectives. Vet Clin Pathol. 2005;34(2):85-99. http://dx.doi. org/10.1111/j.1939-165X.2005.tb00019.x. PMid:15902658.

Clark JAM, Potter M, Harding E. The welfare implications of animal breeding and breeding technologies in commercial agriculture. Livest Sci. 2006;103(3):270-81. http://dx.doi. org/10.1016/j.livsci.2006.05.015.

Destrez A, Haslin E, Elluin G, Gaillard C, Hostiou N, Dasse F, Zanella C, Boivin X. Evaluation of beef herd responses to unfamiliar humans and potential in $\mathrm{fl}$ uencing factors: an exploratory survey on French farms. Livest Sci. 2018;212:713. http://dx.doi.org/10.1016/j.livsci.2018.03.011.

Doornenbal H, Tong AKW, Murray NL. Reference values of blood parameters in beef cattle of different ages and stages of lactation. Can J Vet Res. 1988;52(1):99-105. PMid:3349406.

Ferguson JD, Galligan DT, Thomsen N. Principal descriptors of body condition score in Holstein cows. J Dairy Sci. 1994;77(9):2695-703. http://dx.doi.org/10.3168/jds.S00220302(94)77212-X. PMid:7814740.

Friedewald WT, Levy RI, Fredrickson DS. Estimation of the concentration of low-density lipoprotein cholesterol in plasma, without use of the preparative ultracentrifuge. Clin Chem. 1972;18(6):499-502. http://dx.doi.org/10.1093/ clinchem/18.6.499. PMid:4337382.

Greco D, Stabenfeldt GH. Endocrinologia. In: CUNNIGHAM JG, editor. Tratado de fisiologia veterinária. 3a ed. Rio de Janeiro: Guanabara Koogan; 2008. p. 333-81.

Herdt TH. Ruminant adaptation to negative energy balance. Influences on the etiology of ketosis and fatty liver. Vet Clin North Am Food Anim Pract. 2000;16(2):215-30. http:// dx.doi.org/10.1016/S0749-0720(15)30102-X. PMid:11022337.

Hocquette JF, Bauchart D. Intestinal absorption, blood transport and hepatic and muscle metabolism of fatty acids in preruminant and ruminant animals. Reprod Nutr Dev. 1999;39(1):27-48. http://dx.doi.org/10.1051/rnd:19990102. PMid:10222498.
Kaneko J, Harvey J, Bruss M. Clinical biochemistry of domestic animals. Boston: Academic Press/Elsevier; 2008. $928 \mathrm{p}$.

Kenny DA, Humpherson PG, Leese HJ, Morris DG, Tomos AD, Diskin MG, Sreenan JM. Effect of elevated systemic concentrations of ammonia and urea on the metabolite and ionic composition of oviductal fluid in cattle. Biol Reprod. 2002;66(6):1797-804. http://dx.doi.org/10.1095/ biolreprod66.6.1797. PMid:12021065.

Madureira EH, Pimentel JR. IATF como ferramenta para melhorar a eficiência reprodutiva. In: Reprodução Animal; 2005; Goiania, Brazil. Belo Horizonte: Colégio Brasileiro de Reprodução Animal; 2005.

Mondal M, Prakash BS. Changes in plasma non-esterified fatty acids, glucose and alpha-amino nitrogen and their relationship with body weight and plasma growth hormone in growing buffaloes (Bubalus bubalis). J Anim Physiol Anim Nutr. 2004;88(5-6):223-8. http://dx.doi.org/10.1111/j.14390396.2004.00476.x. PMid:15189427.

Oliveira BMM, Arruda RP, Thomé HE, Maturana Filho M, Oliveira GC, Guimarães CF, Silva LA, Nichi M, Celeghini ECC. Artificial insemination causes uterine hemodynamic alterations in suckled beef cows subjected to an ovulation synchronization program. Livest Sci. 2014;167:449-54. http://dx.doi.org/10.1016/j.livsci.2014.05.027.

Peixoto LAO, Brondani IL, Nörnberg JL, Restle J, Alves Filho DC, Pazini M, Coradini MT, Santos CVM. Protein metabolic profile and conception rate of beef cows kept on nature pasture or supplemented with wheat meal, with or without urea. Cienc Rural. 2006;36(6):1873-7. http://dx.doi. org/10.1590/S0103-84782006000600032.

Rutledge JJ. Use of embryo transfer and IVF to bypass effects of heat stress. Theriogenology. 2001;55(1):10511. http://dx.doi.org/10.1016/S0093-691X(00)00449-0. PMid:11198076.

Shahin M. The effects of positive human contact by tactile stimulation on dairy cows with different personalities. Appl Anim Behav Sci. 2018;204:23-8. http://dx.doi.org/10.1016/j. applanim.2018.04.004.

Shpigel NY, Avidar Y, Bogin E. Value of measurements of the serum activities of creatine phosphokinase, aspartate aminotransferase and lactate dehydrogenase for predicting whether recumbent dairy cows will recover. Vet Rec. 2003;152(25):773-6. http://dx.doi.org/10.1136/vr.152.25.773. PMid:12846288. 
Viana JHM, Ferreira AM, Sá WF, Camargo LSA. Luteal regression and follicular dynamic after spontaneous or cloprostenol induced luteolysis in Gir cattle. Arq Bras Med Vet Zootec. 1999;51(3):257-62. http://dx.doi.org/10.1590/ S0102-09351999000300010.

Wathes DC, Cheng Z, Bourne N, Taylor VJ, Coffey MP, Brotherstone S. Differences between primiparous and multiparous dairy cows in the inter-relationships between metabolic traits, milk yield and body condition score in the periparturient period. Domest Anim Endocrinol. 2007;33(2):20325. http://dx.doi.org/10.1016/j.domaniend.2006.05.004. PMid:16806790.

Financial Support: São Paulo State Research Foundation, process numbers (FAPESP) 2011/22833-9 and (FAPESP) 2014/12757-1. 